\title{
PecS and PecT Coregulate the Synthesis of HrpN and Pectate Lyases, Two Virulence Determinants in Erwinia chrysanthemi 3937
}

\author{
William Nasser, ${ }^{1}$ Sylvie Reverchon, ${ }^{1}$ Regine Vedel, ${ }^{2}$ and Martine Boccara ${ }^{2}$ \\ ${ }^{1}$ Unité de Microbiologie et Génétique UMR CNRS-INSA-UCBL 5122 Domaine Scientifique de la Doua, Université Claude \\ Bernard Lyon I Bâtiment A. Lwoff, 10 rue Raphaël Dubois 69622 Villeurbanne Cedex, France; ${ }^{2}$ Laboratoire de Pathologie \\ Végétale, UMR 217 INRA-INAP/G-Paris 616 rue Claude Bernard 75005 Paris, France
}

Submitted 2 May 2005. Accepted 14 July 2005

Erwinia chrysanthemi strain 3937 is a necrotrophic bacterial plant pathogen. Pectinolytic enzymes and, in particular, pectate lyases play a key role in soft rot symptoms; however, the efficient colonization of plants by $E$. chrysanthemi requires additional factors. These factors include HrpN (harpin), a heat-stable, glycine-rich hydrophilic protein, which is secreted by the type III secretion system. We investigated the expression of hrp $N$ in $E$. chrysanthemi 3937 in various environmental conditions and different regulatory backgrounds. Using lac Z fusions, $h r p N$ expression was markedly influenced by the carbon source, osmolarity, growth phase, and growth substrate. $h r p N$ was repressed when pectinolysis started and negatively regulated by the repressors of pectate lyase synthesis, PecS and PecT. Primer extension data and in vitro DNA-protein interaction experiments support a model whereby PecS represses $h r p N$ expression by binding to the $h r p N$ regulatory region and inhibiting transcript elongation. The results suggest coordinated regulation of $\mathrm{HrpN}$ and pectate lyases by PecS and PecT. A putative model of the synthesis of these two virulence factors in $E$. chrysanthemi during pathogenesis is presented.

Additional keyword: hypersensitive response.

The pectinolytic Erwinia spp. are soft-rotting, gram-negative bacteria that cause severe disease in a wide range of plant species, including many crops of economical importance. They recently have been classified in the resuscitated genus Pectobacterium (Hauben et al. 1998), but the nomenclature has not yet been widely accepted by plant pathologists (Pérombelon 2002). Plant tissue maceration by the soft rot Erwinia spp. is due to the disintegration of the plant cell wall by extracellular enzymes, among which pectinases play a predominant role (Barras et al. 1994; Hugouvieux-Cotte-Pattat et al. 1996). Pectinases are secreted by a type II system encoded by the out genes (Condemine et al. 1992; Reeves et al. 1993). The pecti-

Corresponding author: W. Nasser: Telephone: (33) 4724326 95; Fax: (33) 4724315 84; E-mail: William.nasser@insa-lyon.fr

Current address of M. Boccara: Atelier de Bioinformatique Université Pierre et Marie Curie 12 rue Cuvier 75005 Paris, France.

This article is in the public domain and not copyrightable. It may be freely reprinted with customary crediting of the source. The American Phytopathological Society, 2005. nases of E. chrysanthemi strain 3937 have been investigated by several groups. Five major endo-pectate lyases (Pels) were identified by isoelectrofocusing overlay gels (Bertheau et al. 1984), and the five corresponding pel genes (pelA to pelE) were cloned (Reverchon et al. 1987; Hugouvieux-Cotte-Pattat and Robert-Baudouy 1992). Expression in planta of the pel genes was studied mostly in Saintpaulia ionantha using pel::uidA fusions. pelD was shown to be the first and highest expressed pel gene, whereas pelC, pelB, and pelE were moderately expressed subsequently to pelD (Masclaux et al. 1996). Other factors are important for E. chrysanthemi strain 3937 pathogenicity, such as siderophores (Expert 1999), lipopolysaccharides (Schoonejans et al. 1987), exopolysaccharides (Condemine et al. 1999), or proteins involved in resistance against plant defense mechanisms (El Hassouni et al. 1999; Favey et al. 1995; Lopez-Sollania et al. 1998; Reverchon et al. 2002; Santos et al. 2001).

Production of virulence factors, particularly the Pels, is tightly regulated and responds to several environmental conditions and metabolic stimuli, including growth phase, catabolic repression, pectin or plant extract, temperature, osmolarity, $\mathrm{pH}$, and iron (Expert 1999; Hugouvieux-Cotte-Pattat et al. 1996). Several regulators modulating the expression of virulence genes in E. chrysanthemi have been previously characterized (Franza et al. 1999; Nasser and Reverchon 2002; Nasser et al. 1992, 1998; Nomura et al. 1998; Praillet et al. 1996; Reverchon et al. 1991, 1994, 1997; Surgey et al. 1996). The induction of pel gene expression by pectic compounds is mediated by KdgR (Nasser et al. 1994; Reverchon et al. 1991). The induction by plant extracts and iron starvation is mediated by Pir (Nomura et al. 1998) and Fur (Franza et al. 1999), respectively. ExpR is a quorum-sensing regulator that participates in the modulation of pel gene expression in response to $\mathrm{N}$-acyl-homoserine lactones (acyl-HSLs) generated by the ExpI synthase (Nasser et al. 1998).

An hrp locus also contributes to Erwinia pathogenicity (Alfano and Collmer 1997). The hrp genes encode proteins that constitute the type III secretion system required for pathogenicity in host plants and elicitation of the defensive hypersensitive response (HR) in nonhost plants. The HR is characterized by rapid, localized cell death at the site of infection. This cell death response is associated with the induction of defense-related genes, which play important roles in containing pathogen propagation (Dangl and Jones 2001; Scheel 1998). A characteristic feature of an HR is a sustained increase of reactive oxygen species (ROS). The harpin protein $(\mathrm{HrpN})$ is one of the proteins translocated by the Hrp secretion system (Alfano 
et al. 1996). Harpin-induced cell death as well as generation of ROS has been reported for several plants (Boccara et al. 2001; Desikan et al. 1998; Krause and Durner 2004; Wei et al. 1992; Xie and Chen 2000). E. chrysanthemi also produces a harpin protein $\left(\mathrm{HrpN}_{\mathrm{Ech}}\right)$, and $h r p N_{E c h}$ mutants display reduced virulence (Bauer et al. 1995; Yang et al. 2002). In contrast to the pel genes, little is known about the control of $h r p N_{E c h}$ gene expression. Recently, the expression of $h r p N_{E c h}$ was shown to be dependent on the alternative sigma factor $\mathrm{HrpL}$ and is growth-phase regulated (Ham et al. 2004). However, the growth-phase regulation of $h r p N_{E c h}$ is independent of the ExpIExpR system (Ham et al. 2004). Here, we report the results of investigations of $h r p N_{E c h}$ expression in strain E. chrysanthemi 3937 during different conditions and stages of growth, including the carbon source, osmolarity, growth-phase, and the nature of the growth medium.

\section{RESULTS}

\section{hrpN from strain 3937 is weakly expressed in rich and} minimal salts media and is surface induced.

Plasmid pCPN2, containing the $h r p N$ gene, was introduced into Escherichia coli POI1734 strain for miniMu transposon mutagenesis. Different miniMu insertions were analyzed by restriction mapping. Constructs displaying a transcriptional $h r p N_{E c h}:$ lacZ organization were sequenced with a $\mathrm{Mu}$ end primer (5'-CCGAATAATCCAATGTCC-3') and the pRV85 insertion was retained. The insertion in pRV85 was located at nucleotide 744 from the $h r p N$ start codon. $\beta$-Galactosidase synthesis by $E$. coli strain NM522, transformed by the construct pRV85, confirmed that the corresponding MudI1734 insertion resulted in a lac $Z$ fusion. The construction was marker exchanged into the Erwinia chrysanthemi A350 chromosome (strain A350 is a lacZ derivative of the 3937 strain recently sequenced). The generated strain was called A4353 (Table 1).
HrpN is known to be involved in the early stage of infection (Bauer et al. 1994); therefore, the expression of $h r p N_{E c h}:: l a c Z$ was examined for modulation by various environmental conditions similar to those encountered in the intercellular spaces of plant tissues, including liquid minimal salts medium (M63 and M9) supplemented with glycerol or various sugars (glucose, fructose, arabinose, and sucrose), liquid-rich Luria broth (LB) medium, and solid agar plate media. The results led to the following conclusions: i) the expression level was low in liquid minimal salts medium containing glycerol (Fig. 1A), as well as in LB medium (4.2 Miller units for LB versus 4.6 Miller units for M63 plus glycerol); ii) the level of expression was influenced by the carbon source, the highest levels being achieved with sucrose, followed by glucose and fructose (Fig. 1A); and iii) the expression level was increased at least fivefold when bacteria were grown on solid medium, regardless of the medium (Fig. 1B; data not shown for LB and M63 plus glycerol or sucrose media). Based on the results, the minimal salts medium supplemented with glucose was selected for the subsequent experiments on $h r p N_{E c h}$ expression.

We further investigated the effect of growth phase and osmolarity of the growth medium on the expression of $h r p N_{E c h}$. Media with low (M63/2) or high (M63 plus 100 to $300 \mathrm{mM}$ $\mathrm{KCl}$ or $\mathrm{NaCl}$ ) osmolarity reduced the $h r p N_{E c h}$ expression (Fig. $1 C)$. It is important to note that the level of the $h r p N_{E c h}$ expression modulation by osmolarity depends on the nature of the carbon source used. Indeed, we observed only a twofold decrease in the $h r p N_{E c h}$ expression between growth in M63 compared with M63 plus $300 \mathrm{mM} \mathrm{NaCl}$ in the presence of glycerol as the carbon source (data not shown), instead of a fivefold decrease in the presence of glucose (Fig. 1C) or sucrose (data not shown).

The data revealed that the expression level of $h r p N_{E c h}$ also was dependent on growth phase, the maximal expression occurring during late exponential growth (Fig. 2). However as

Table 1. Bacterial strains, plasmids, and phages used in this work

\begin{tabular}{|c|c|c|}
\hline Strain & Relevant characteristics and use ${ }^{a}$ & Reference or source \\
\hline \multicolumn{3}{|c|}{ Escherichia coli } \\
\hline NM522 & $\Delta($ lac-proAB) thi hsd-5 supE (F'proAB+ lacIq lacZ $\Delta M 15)$ & Stratagene \\
\hline POI1734 & $F^{-}$araD1394lacU169 rpsL thi with Mu dI1734 & Castilho et al. 1984 \\
\hline \multicolumn{3}{|c|}{ Erwinia chrysanthemi } \\
\hline 3937 & Wild-type strain isolated from Saintpaulia ionantha & Kotoujansky et al. 1982 \\
\hline A 350 & $\operatorname{lm} T($ con $) \operatorname{lacZ2}$ & Hugouvieux-Cotte-Pattat and Robert-Baudouy 1985 \\
\hline A 1880 & $\operatorname{lmrT}($ con) lacZ2 pelC::uidA Km & Hugouvieux-Cotte-Pattat et al. 1992 \\
\hline A1798 & $\operatorname{lmrT}($ con) lacZ2 pelD::uidA $\mathrm{Km}$ & \\
\hline A3719 & $\operatorname{lmrT}($ con) lacZ2 $k d g R:: \operatorname{miniTn} 5-\mathrm{Sm}$ & Laboratory collection \\
\hline A 1524 & $\operatorname{lmrT}($ con) lacZ2 pecS::MudIIPR13 & Reverchon et al. 1994 \\
\hline A 2148 & lmrT(con) lacZ2 pecT::uidA $\mathrm{Cm}$ & Surgey et al. 1996 \\
\hline A3810 & $\operatorname{lm} T$ (con) lacZ2 pir:: $\mathrm{Cm}$ & Laboratory collection \\
\hline A 2757 & $\operatorname{lmr} T$ (con) lacZ2 expI::Cm & Nasser et al. 1998 \\
\hline A3009 & $\operatorname{lmr} T(\mathrm{con}) \mathrm{lacZ2} \operatorname{expR}: \mathrm{Cm}$ & Nasser et al. 1998 \\
\hline A4353 & $\operatorname{lmrT}(\mathrm{con}) \operatorname{lacZ2}$ hrpN::lacZ & This work \\
\hline A4354 & $\operatorname{lmrT}$ (con) lacZ2 pecS::MudIIPR13 hrpN::lacZ & This work \\
\hline A4355 & $\operatorname{lmrT}$ (con) lacZ2 pecT::uidA Cm hrpN::lacZ & This work \\
\hline A4356 & $\operatorname{lmrT}$ (con) lacZ2 kdgR::miniTn5-Sm hrpN::lacZ & This work \\
\hline A4357 & $\operatorname{lmrT}($ con) lacZ2 pir::Cm hrpN::lacZ & This work \\
\hline A4358 & 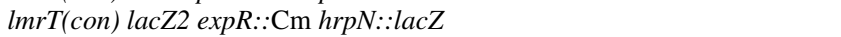 & This work \\
\hline A4359 & $\operatorname{lmrT}($ con) lacZ2 expI::Cm hrpN::lacZ & This work \\
\hline \multicolumn{3}{|l|}{ Plasmids } \\
\hline pGEM-T & Cloning vector, $\mathrm{Ap}^{\mathrm{r}} l a c Z^{\prime}$ & Promega \\
\hline pWN3013 & pGEM-T with the 424-bp fragment containing the $h r p N$ regulatory region & This work \\
\hline pCPN2 & pUC18 with a $4.2-\mathrm{kb}$ fragment containing the $h r p N$ gene & Yang et al. 2002 \\
\hline pRV85 & pCPN2 with Mud11734 phage generating a lacZ::hrpN fusion & This work \\
\hline \multicolumn{3}{|c|}{ 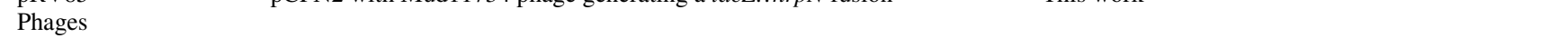 } \\
\hline PhiEC2 & General transducing phage of Erwinia chrysanthemi & Résibois et al. 1982 \\
\hline MudI1734 & miniMu lacZ transcription fusion phage (lacZ-Km) & Castilho et al. 1984 \\
\hline
\end{tabular}

${ }^{a}$ Genotype symbols are according to Berlyn (1998). $\operatorname{lmr} T(\mathrm{con})$ indicates that the transport system encoded by the gene $\operatorname{lm} T$, which mediates the entry of lactose, melibiose, and raffinose into the cells, is constitutively expressed. lac $Z^{\prime}$ indicates that the $3^{\prime}$ end of this gene is truncated. Km $=\mathrm{Kanamycin}, \mathrm{Cm}=$ chloramphenicol, $\mathrm{Ap}=$ ampicillin, and $\mathrm{Sm}=$ streptomycin. 
previously reported (Ham et al. 2004), the grow-phase-dependent elevated expression of $h r p N$ is independent of the quorumsensing signal $N$-(3-oxo-hexanoyl)-L-homoserine lactone (OHHL) produced by expI (data not shown).

$h r p N$ and pel genes are differently expressed in planta.

To elucidate whether the regulatory effect of environmental or physiological conditions on pel and $h r p N_{E c h}$ gene expression observed under laboratory conditions had physiological relevance during plant infection by $E$. chrysanthemi, we analyzed the in planta expression of $h r p N_{E c h}$, pelD, and pelC genes. We first studied the virulence of an $h r p N_{E c h}$ mutant in witloof chicory leaves. After inoculation of the bacterial suspension $\left(10^{6}\right.$ $\mathrm{CFU}$ ), the progression of infection was followed by a daily measurement of the macerated surface areas. The growth rate of the mutant and wild-type strains was similar for the first 72 $\mathrm{h}$ after inoculation (data not shown). We observed in the case of the A350 strain, $24 \mathrm{~h}$ after inoculation, a consistent maceration of most of the inoculated leaves, whereas there was a delay in the appearance of symptoms in the $h r p N_{E c h}$ mutant.
However, $72 \mathrm{~h}$ post inoculation, the macerated surfaces were almost identical for the two strains (Table 2). Thus, we observed in witloof chicory leaves what previously has been observed in Saintpaulia plants (Yang et al. 2002), a delay in symptom development with the $h r p N_{E c h}$ mutant. We then studied the expression of $h r p N_{E c h}:: l a c Z$ at different times after the infection of witloof chicory leaves. We observed a four- to fivefoldinduction of $h r p N_{E c h}$ expression in planta within less than $8 \mathrm{~h}$ after inoculation, reaching a maximum after $24 \mathrm{~h}$, then decreasing (Fig. 3) and disappearing after $72 \mathrm{~h}$ (not shown). In parallel, we followed the expression of pelC::uidA and pelD::uidA reporters. Expression of these two pel genes increased shortly after infection and was maintained at a relatively high level after 48 h (Fig. 3). Consistently, Pel activity, which could not be detected earlier than $24 \mathrm{~h}$ after infection, increased over time (Fig. 3). These results show that, during infection, $h r p N_{E c h}$ is expressed transiently; the strong expression observed in the first steps of infection matched the previous evidence that the Hrp system was involved in the early stage of infection (Bauer et al. 1994). Moreover, the in planta expression pattern of

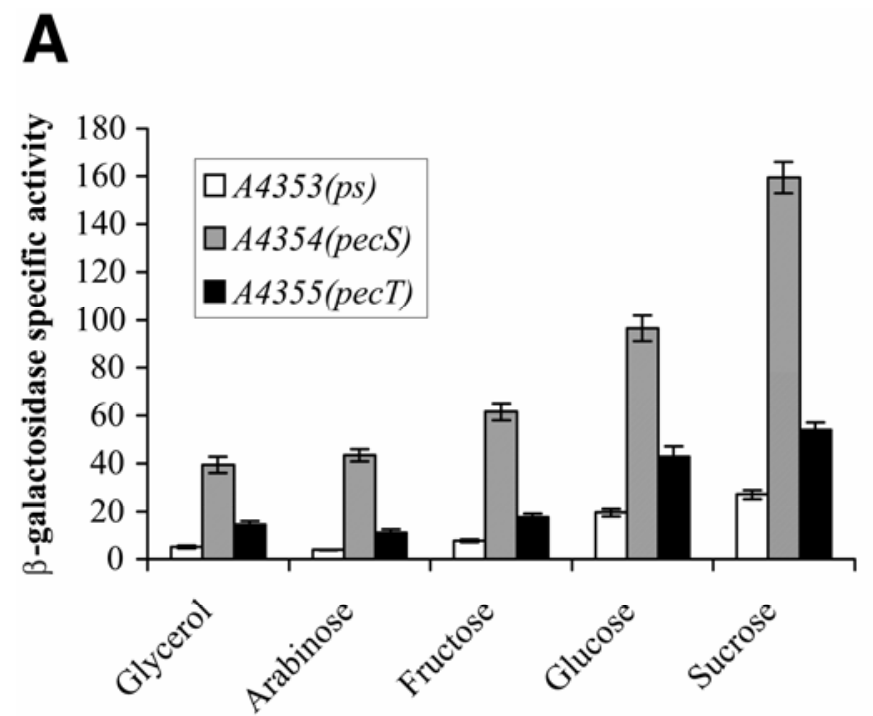

D
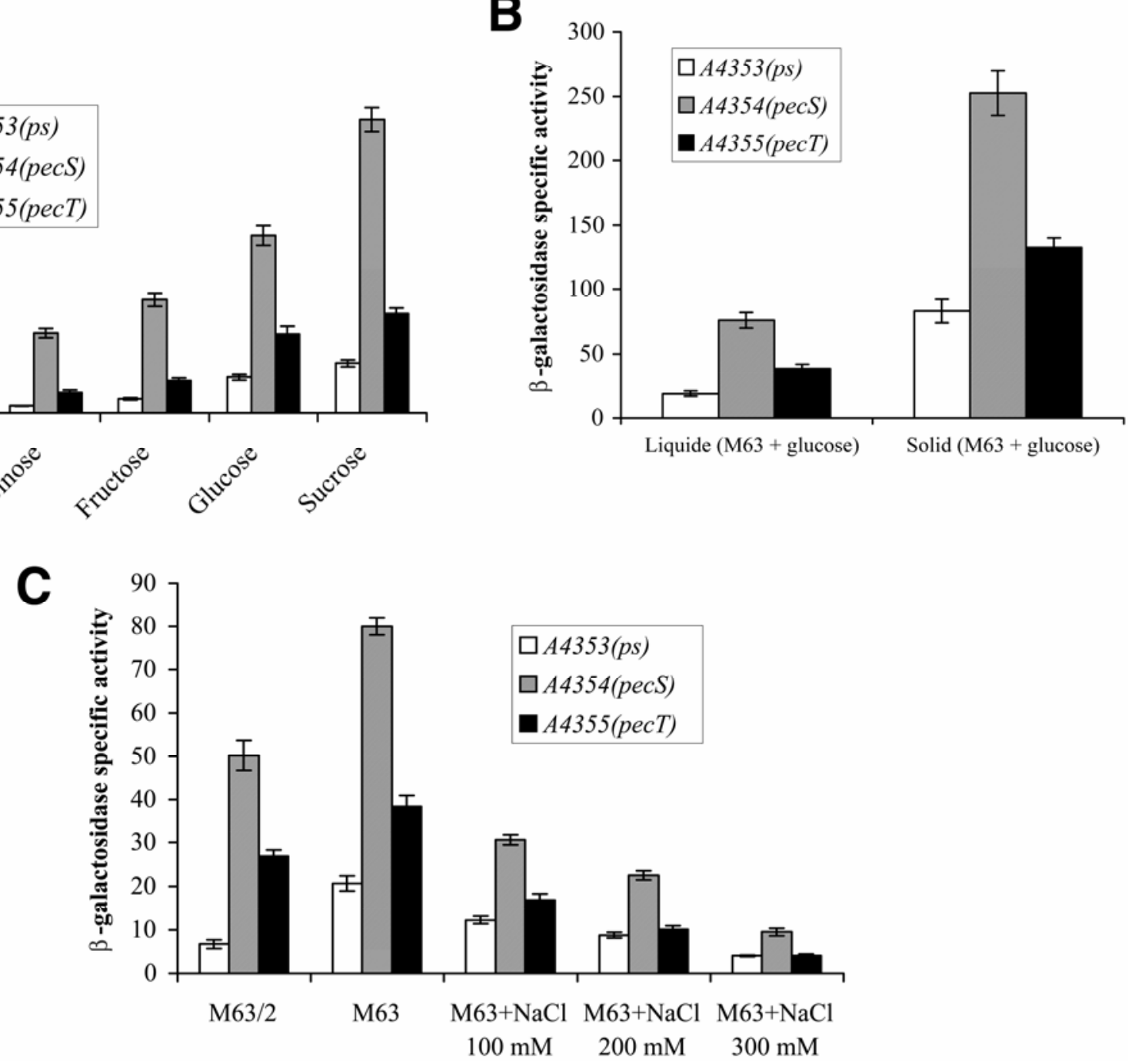

Fig. 1. Expression of Erwinia chrysanthemi $h r p N_{E c h}:: l a c Z$ in response A, to different carbon sources, $\mathbf{B}$, to the media composition, and $\mathbf{C}$, to osmolarity during growth in minimal salts M63 medium. Glucose was used as carbon source in B and C, and growth assays in A and C were performed in liquid medium. Bacteria A4353 ( $p s=$ parental strain; $\left.\mathrm{PecS}^{+}, \mathrm{PecT}^{+}\right)$, A4354 $\left(\mathrm{PecS}^{-}\right)$, and $\mathrm{A} 4355\left(\mathrm{PecT}^{-}\right)$were grown overnight (stationary phase) in appropriate media at $30^{\circ} \mathrm{C}$, and the cultures were assayed for $\beta$-galactosidase activity. Results are expressed in Miller units; the presented values for strains A4353, A4354, and A4355 were subtracted from the residual values obtained in the parental counterparts A350, the pecS mutant A1524, and the pecT mutant A2148, respectively. Each value represents the mean of three experiments. Bars indicate the standard deviation. Results similar to those presented in B were obtained when rich Luria broth medium was used instead of minimal medium. 
$h r p N_{E c h}$ was consistent with the involvement of HrpN in the stimulation of ROS production, which has been shown to occur as early as $3 \mathrm{~h}$ after infection of Saintpaulia plants by E. chrysanthemi (Santos et al. 2001).

\section{PecS and PecT repress hrpN.}

Pectinolysis in E. chrysanthemi requires several regulators (Hugouvieux-Cotte-Pattat et al. 1996; Nasser and Reverchon 2002). Transduction with phage phiEC2 was used to transfer the $h r p N_{E c h}:: l a c Z$ fusion into different genetic backgrounds in order to explore the relationship between $h r p N_{E c h}$ expression and pectinolysis. Although a mutation in the $k d g R$, $\operatorname{expR}$, or pir backgrounds had no effect on $h r p N_{E c h}$ transcription (data not shown), $h r p N_{E c h}$ expression increased 4- to 14-fold and 2.5- to 5 -fold in the pecS and pecT mutants, respectively, depending on the growth phase (Fig. 2). These results establish that PecS and PecT repress $h r p N_{E c h}$ expression. The $h r p N_{E c h}$ expression modulations by the stated environmental or physiological conditions are conserved in the pecS and pecT backgrounds (Figs. 1 and 2); thus, the signals modulating the action of these two regulators on $h r p N_{E c h}$ expression are not elucidated.

To test whether transcriptional regulation of $h r p N$ is achieved by a direct binding of PecS to the promoter region, in vitro DNA-protein interactions were performed. We recently succeeded in determining the PecS DNA binding consensus $\left(\mathrm{C}_{-11} \mathrm{G}_{-10} \mathrm{~A}_{-9} \mathrm{~N}_{-8} \mathrm{~W}_{-7} \mathrm{~T}_{-6} \mathrm{C}_{-5} \mathrm{G}_{-4} \mathrm{~T}_{-3} \mathrm{~A}_{-2}\right) \mathrm{T}_{-1} \mathrm{~A}_{0} \mathrm{~T}_{1} \quad\left(\mathrm{~T}_{2} \mathrm{~A}_{3} \mathrm{C}_{4} \mathrm{G}_{5} \mathrm{~A}_{6} \mathrm{~N}_{7}\right.$ $\mathrm{N}_{8} \mathrm{~N}_{9} \mathrm{C}_{10} \mathrm{G}_{11}$ ) (Rouanet et al. 2004). A sequence displaying a significant identity ( $58 \%$ ) with the defined consensus was identified in the $h r p N_{E c h}$ translation initiation region (Fig. 4). The binding of PecS to the $h r p N_{E c h}$ regulatory region (PhrpN) first was measured by band-shift assays. PecS could interact specifically with PhrpN ( -323 to +101 versus the translation initiation codon ATG) (Fig. 4A). The apparent dissociation constant $\left(K_{\mathrm{d}}\right)$ was $25 \mathrm{nM}$. This finding, therefore, suggests that $\mathrm{PecS}$ is capable of directly regulating the expression of the $h r p N_{E c h}$ gene. For PecT, we were not able to determine a consensus sequence, because this protein aggregates when overproduced (Castillo et al. 1998). Thus, characterization of the PecT mechanism on $h r p N_{E c h}$ was not further analyzed.

To place the PecS binding site at PhrpN into context, it was necessary to attempt to establish the $h r p N_{E c h}$ transcription start point. Primer extension analysis with RNA from the end of exponential phase cultures (optical density $[\mathrm{OD}]=0.7$ ) of the $E$. chrysanthemi parental strain A350, or its pecS and pecT derivatives, revealed that $h r p N_{E c h}$ transcription was initiated at 91 bases upstream of the translation start (Fig. 4B). In addition to
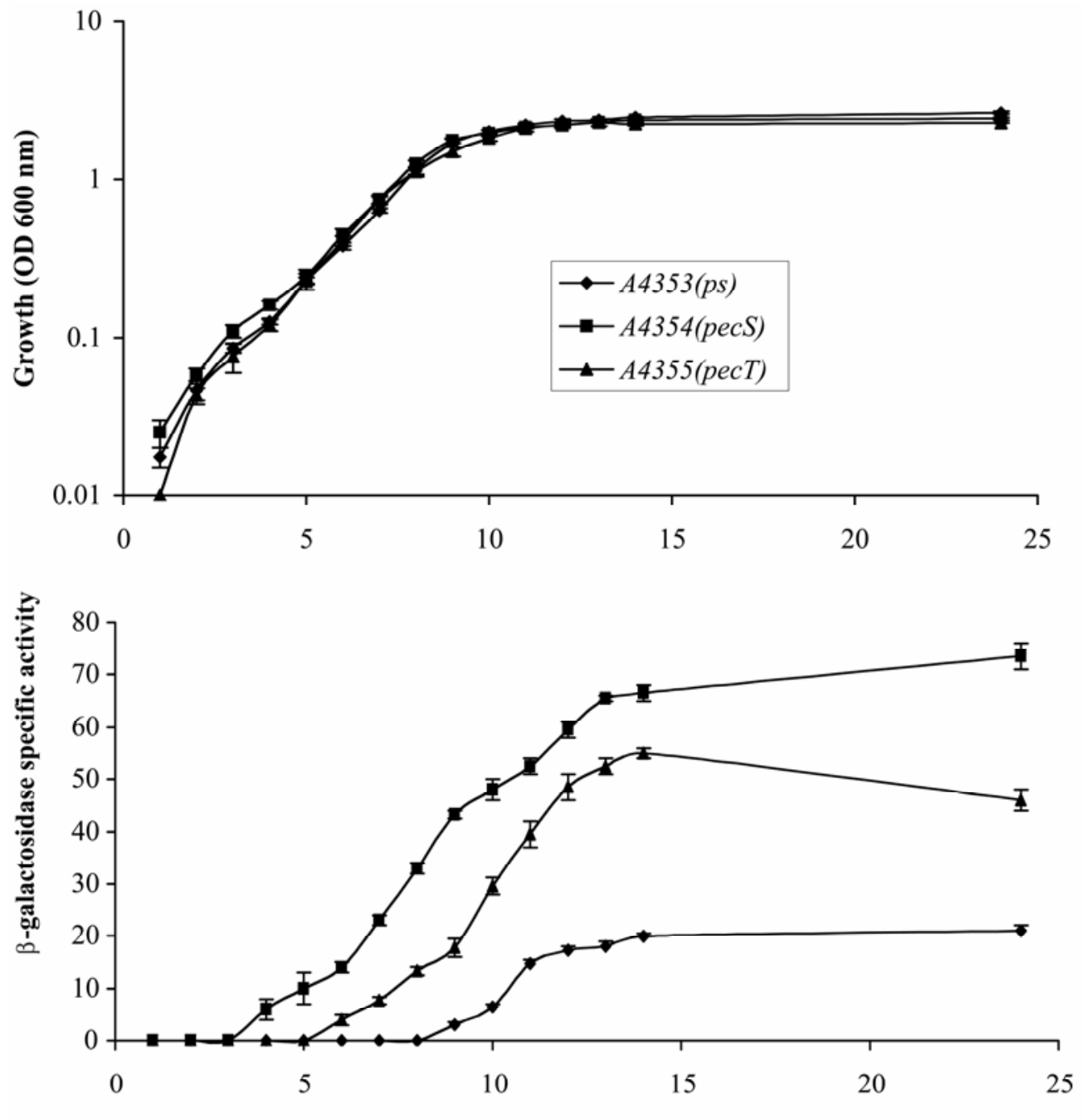

Time in hours

Fig. 2. Cell-density-dependent expression of an $h r p N_{E c h}:: l a c Z$ fusion in Erwinia chrysanthemi $\mathrm{A} 4353, \mathrm{~A} 4354$, and A4355. Bacteria were grown at $30^{\circ} \mathrm{C}$ in liquid minimal salts M63 medium containing glucose, and 1-ml samples were taken every hour. Results are expressed in Miller units; the presented values for A4353, A4354, and A4355 were subtracted from the residual values obtained in the parental counterparts A350, the pecS mutant A1524, and the pecT mutant A2148, respectively. Each value represents the mean of three experiments. Bars indicate the standard deviation. 
the discussed transcription initiation site, a second band $11 \mathrm{bp}$ shorter also was observed. The relevance of this band, which might be the result of incomplete elongation or an alternative transcription initiation site of $h r p N$, has still to be elucidated.

Table 2. Representative disease lesions caused by the lacZ Erwinia chrysanthemi $\mathrm{A} 350$ and its $h r p N$ derivative on witloof chicory leaves

\begin{tabular}{lccc}
\hline & \multicolumn{2}{c}{ Size of maceration $\left.\mathbf{( c m}^{\mathbf{2}}\right)^{\mathbf{a}}$} \\
\cline { 3 - 4 } Strain & Inf./inoc. $^{\mathbf{b}}$ & $\mathbf{2 4} \mathbf{~ h}$ & $\mathbf{7 2 ~} \mathbf{~}$ \\
\hline A350 (parental strain) & $23 / 25$ & $3.2 \pm 0.8$ & $83 \pm 25$ \\
A350 hrpN::lacZ (A4353) & $22 / 25$ & $1.6 \pm 0.4$ & $81 \pm 31$ \\
\hline
\end{tabular}

${ }^{a}$ Values are the product of the length and width of the macerated area.

${ }^{\mathrm{b}}$ Number of leaves infected/inoculated. Bacterial suspension $\left(2 \mu \mathrm{l}, 5 \times 10^{8}\right.$ $\mathrm{CFU} / \mathrm{ml}$ ) was inoculated, without wounding, and lesions were measured at 24 and $72 \mathrm{~h}$ after inoculation.
Consistent with the previous gene fusion studies, a more abundant accumulation of $h r p N_{E c h}$ transcripts (nine- and threefold) was observed in the pecS and pecT backgrounds, respectively, compared with the parental strain. Seven bases further upstream, there were potential HrpL alternative sigma factor (ECF subfamily) consensus elements TCACTC $\left(\mathrm{N}_{16}\right)$ GGAACC (Frederick et al. 2001; Wei and Beer 1995). This reinforced the feature of a requirement of $\mathrm{HrpL}$ for $h r p N_{E c h}$ expression (Ham et al. 2004; Yap et al. 2005) as previously reported in Pantoea stewartii subsp. stewartii, E. amylovora, and E. chrysanthemi EC16 (Frederick et al. 2001; Ham et al. 2004; Wei and Beer 1995). Accordingly, the $h r p N_{E c h}$ transcription start point mapped here is located in an appropriate context.

The regions of the DNA segment that interact with PecS were identified by DNase I footprinting analysis (Fig. 4C and D). At a PecS concentration of $20 \mathrm{nM}$, only an increased inten-
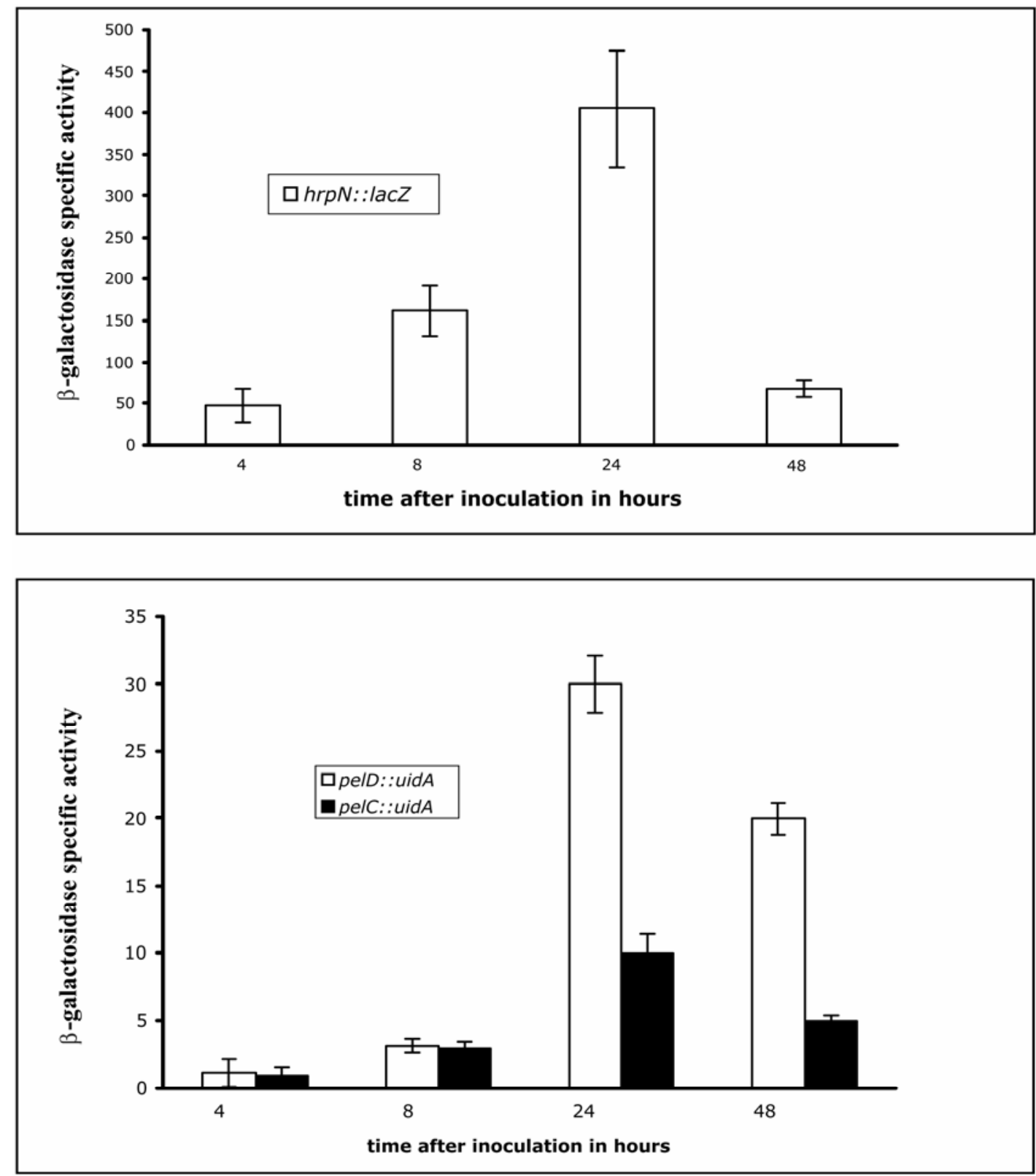

Fig. 3. Expression of Erwinia chrysanthemi A350 hrp $N_{E c h}:$ lacZ (A4353), pelC::uidA (A1880), and pelD::uidA (A1798) in chicory leaves. Bacteria were inoculated into witloof chicory leaves and the inoculated and macerated area was collected, cells were counted, and $\beta$-galactosidase, $\beta$-glucuronidase, and pectate lyase activities were measured. The $\beta$-galactosidase activities presented represent the difference between the values of the $h r p N_{E c h}:: l a c Z$ fusion and the residual activities obtained in the parental strain A350. $\beta$-galactosidase activities are expressed in Miller units, $\beta$-glucuronidase-specific activity is expressed as nanomoles of $p$ nitrophenol produced per minute per milligram of bacterial dry weight, pectate lyase-specific activity is expressed as nanomoles of unsaturated product liberated per minute per milligram of bacterial dry weight. Each value represents the mean of three experiments. Bars indicate the standard deviation. 
sity of certain digested bands $(+67,+68,+71,+80$, and +123$)$ was observed, compared with the profile of the control digestion performed in the absence of PecS. Increasing the PecS concentration up to $50 \mathrm{nM}$ resulted in the appearance of a strong protected area extending from +80 to +114 , relative to the transcription initiation site, and of two regions located apart from the protected area $(+81$ to +64 and +115 to +128$)$ with a modified intensity in several digested DNA fragments (increased or decreased). Further increasing the PecS concentration up to $250 \mathrm{nM}$ did not significantly modify the digestion pattern compared with that obtained in the presence of $50 \mathrm{nM}$ of PecS. It is important to note that the strongly protected region contains the PecS consensus sequence. Overall, these results indicate that $\mathrm{PecS}$ directly represses the $h r p N_{E c h}$ gene expression by interacting with the predicted binding site.

\section{DISCUSSION}

Coordination of virulence factor synthesis is central to pathogenicity. We found that, in E. chrysanthemi, the synthesis of two functions essential for pathogenicity, $\mathrm{HrpN}_{E c h}$ and Pels, are regu- lated in a coordinated manner by the PecS and PecT regulators. Moreover, we showed that expression of $h r p N$ is modulated by the medium composition, growth phase, and osmolarity.

The most notable feature of E. chrysanthemi 3937 hrp $N_{E c h}$ gene regulation by environmental conditions was the high level of expression when bacteria are grown in a minimal salts medium containing sucrose or glucose as the carbon source and when they are in contact with the solid surface. These finding are particularly relevant because these two conditions are presumed to mimic the environment bacteria encounter in plant tissue. Similar regulation of $h r p N$ expression previously was observed for various pathogens, including $E$. amylovora (Wei et al. 1992) and Pseudomonas syringae (Hutcheson 1997). These two signals (presence of sucrose or glucose and contact with solid surface) could be important in modulating HrpN synthesis during plant infection by E. chrysanthemi. The hypothesis of $h r p N$ induction by plant cell surface is supported by recent results establishing that cuticle lipid composition modulates type III gene expression in $P$. syringae (Xiao et al. 2004). We also pointed out that $h r p N_{E c h}$ expression is reduced by low and high osmolarities. Plant tissues usually display a
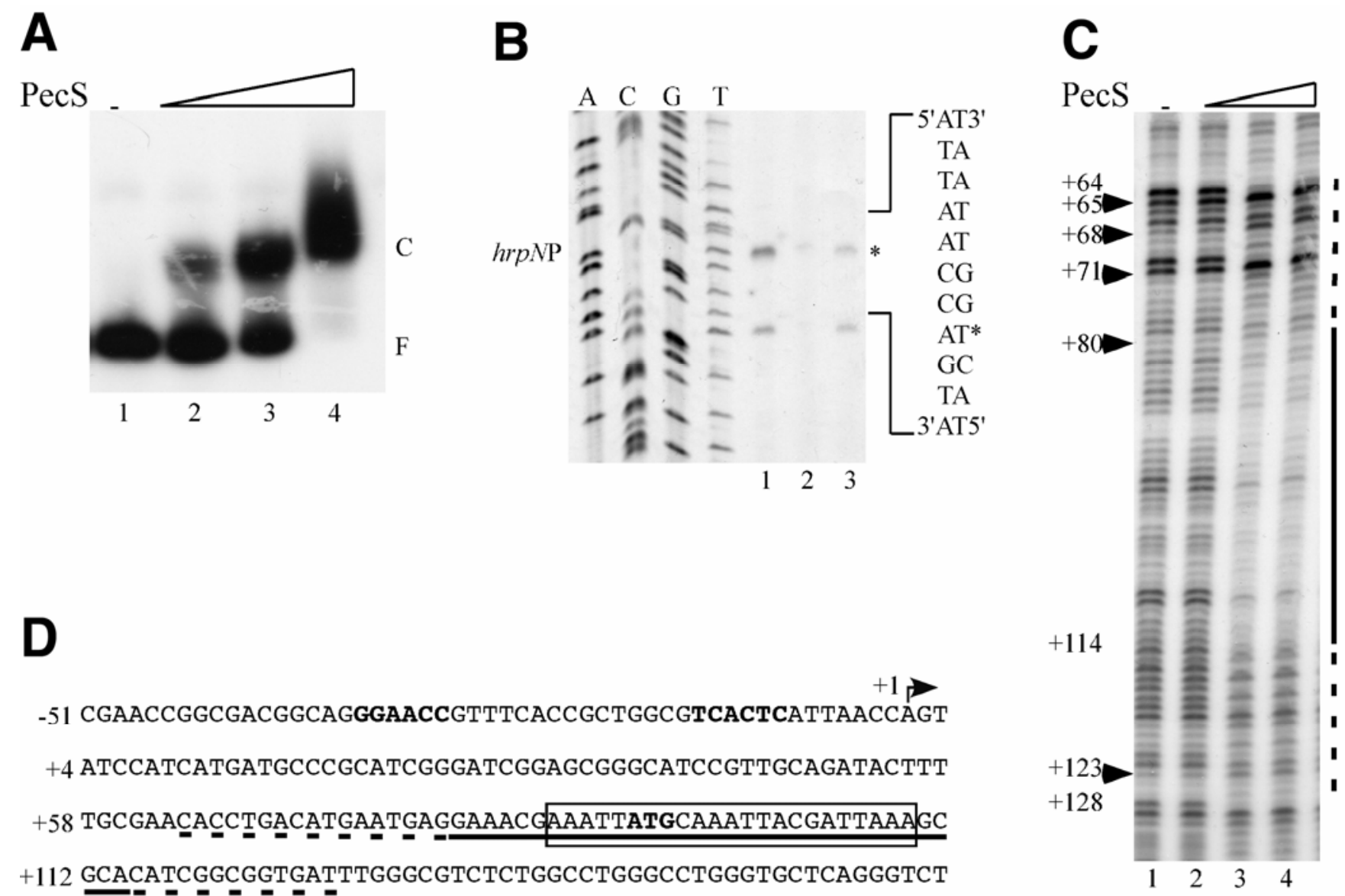

D

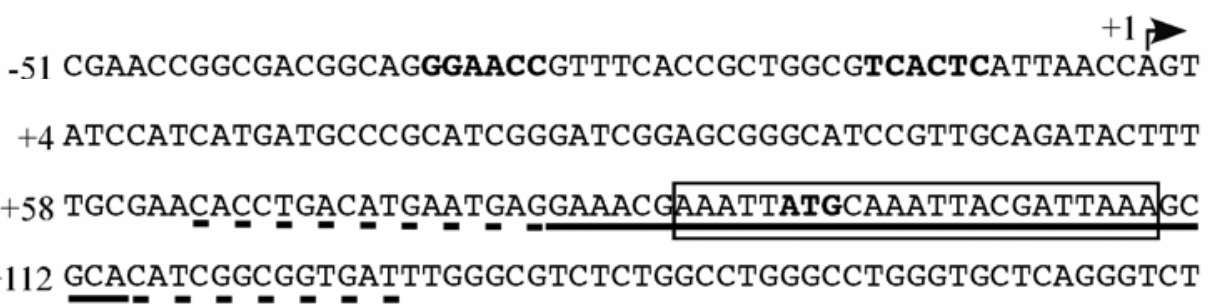

Fig. 4. Effect of the pecS and pecT mutations on the $h r p N_{E c h}$ transcripts and analysis of PecS binding on the $h r p N_{E c h}$ regulatory region. In vitro DNA-protein interaction experiments were performed with a 465-bp DNA fragment containing the $h r p N$ operator/promoter region PhrpN (424-bp, -323 to +101 , versus the translation initiation codon ATG). A, Band-shift assay. Lane 1, no protein; lanes 2 to 4, DNA with 20, 50 , and 250 nM PecS, respectively. The position of free DNA (F) and the PecS-DNA complexes (C) are indicated. B, Identification of the transcriptional start site of Erwinia chrysanthemi A350 hrpN Ech $_{\text {by }}$ primer extension experiments. The reactions were performed with $10 \mu \mathrm{g}$ of RNA extracted from the parental strain A350 (lane 2 ), its pecS derivative A1524 (lane 1), and its pecT derivative A2148 (lane 3). DNA sequencing ladders were generated with the same primer (lanes A, C, G, and T). The retained transcriptional start site is indicated by an asterisk. C, DNase I footprinting analysis on the top strand of the regulatory region. Lane 1 , no protein; lanes 2 to 4, DNA with 20, 50, and $250 \mathrm{nM}$ PecS, respectively. The arrowheads indicate hypersentivities induced by binding of PecS on PhrpN. The regions protected and modified by PecS are indicated on the right by the thick and dashed lines, respectively. The sequences are numbered with respect to the transcriptional start site of $h r p N_{E c h}$. D, Sequence of the $h r p N_{E c h}$ regulatory region. The regions protected and modified by PecS are indicated as in C. The start point of transcription is indicated by an arrow, and the sequences showing significant similarity with the PecS DNA-binding consensus $\left(\mathrm{C}_{-1} \mathrm{G}_{-10} \mathrm{~A}_{-9} \mathrm{~N}_{-8} \mathrm{~W}_{-7} \mathrm{~T}_{-6} \mathrm{C}_{-5} \mathrm{G}_{-}\right.$ $\left.{ }_{4} \mathrm{~T}_{-3} \mathrm{~A}_{-2}\right) \mathrm{T}_{-1} \mathrm{~A}_{0} \mathrm{~T}_{1}\left(\mathrm{~T}_{2} \mathrm{~A}_{3} \mathrm{C}_{4} \mathrm{G}_{5} \mathrm{~A}_{6} \mathrm{~N}_{7} \mathrm{~N}_{8} \mathrm{~N}_{9} \mathrm{C}_{10} \mathrm{G}_{11}\right.$ ) (Rouanet et al. 2004) are boxed. The potential hrp alternative sigma factor HrpL binding elements (Wei and Beer 1995; Frederick et al. 2001), as well as the translation initiation codon ATG, are in bold characters. 
relatively high osmolarity (Pérombelon 2002) but water disponibility in plant varies during infection, essentially because cell lysis in macerated tissues leads to a modification in water distribution between the different cellular compartments (wall, intercellular spaces, cytoplasm, and vacuole) (Pérombelon 2002). Thus, osmolarity might contribute to the modulation of $h r p N_{E c h}$ expression during pathogenesis. The high osmolarity encountered in the plant tissues at the beginning of the infection may prevent an early elevated expression of $h r p N_{E c h}$ during the state of latency of the bacteria.

Our results partially agree with those recently published by Ham and associates (2004). Unlike strain EC16, strain 3937 poorly expresses $h r p N_{E c h}$. However, $h r p N_{E c h}$ from strain 3937 was expressed similarly in LB-rich medium and in glycerol minimal salts media (4.2 Miller units versus 4.6 Miller units, respectively). Moreover, as previously reported in E. carotovora (Mukherjee et al. 1997), our investigations on E. chrysanthemi 3937 revealed a strong stimulation of the $h r p N_{E c h}$ gene expression by sucrose and glucose, whereas E. chrysanthemi EC16 exhibited stimulation by sucrose only (Ham et al. 2004). These discrepancies could be explained by differences in experimental conditions or genotypic variation in the E. chrysanthemi strains, as previously suggested (Ham et al. 2004).
In synthetic media, the temporal expression of $h r p N_{E c h}$ is similar to the expression of genes for various extracellular enzymes, including pel (Barras et al. 1994; Hugouvieux-CottePattat et al. 1992). The relevance of $\mathrm{HrpN}_{E c h}$ induction by the growth phase is, at present, unclear because previous work has suggested an involvement of $\mathrm{HrpN}$ in the early stage of infection (Bauer et al. 1994). Moreover, the results obtained in studies performed on synthetic media diverge from those obtained in planta, which showed a strong expression of $h r p N_{E c h}$ during the first hours of infection (i.e., at low cellular density). The most probable explanation could reside in the fact that $h r p N_{E c h}$ expression in planta is modulated by various signals and that those encountered in the first steps of infection, such as acidic pH (Ham et al. 2004) or contact with a solid surface, were the most relevant. However, it cannot be excluded that a late $h r p N_{E c h}$ stimulation takes place in particular conditions not yet determined in planta. By contrast, the occurrence of Pel activity in planta globally fits the growth phase regulation observed in synthetic media. Thus, the decrease in $h r p N_{E c h}$ expression is correlated with pectate lyase accumulation, indicative of coregulatory circuits.

In vivo gene fusion data and transcript quantification experiments revealed that PecS and PecT repress $h r p N_{E c h}$ expression.

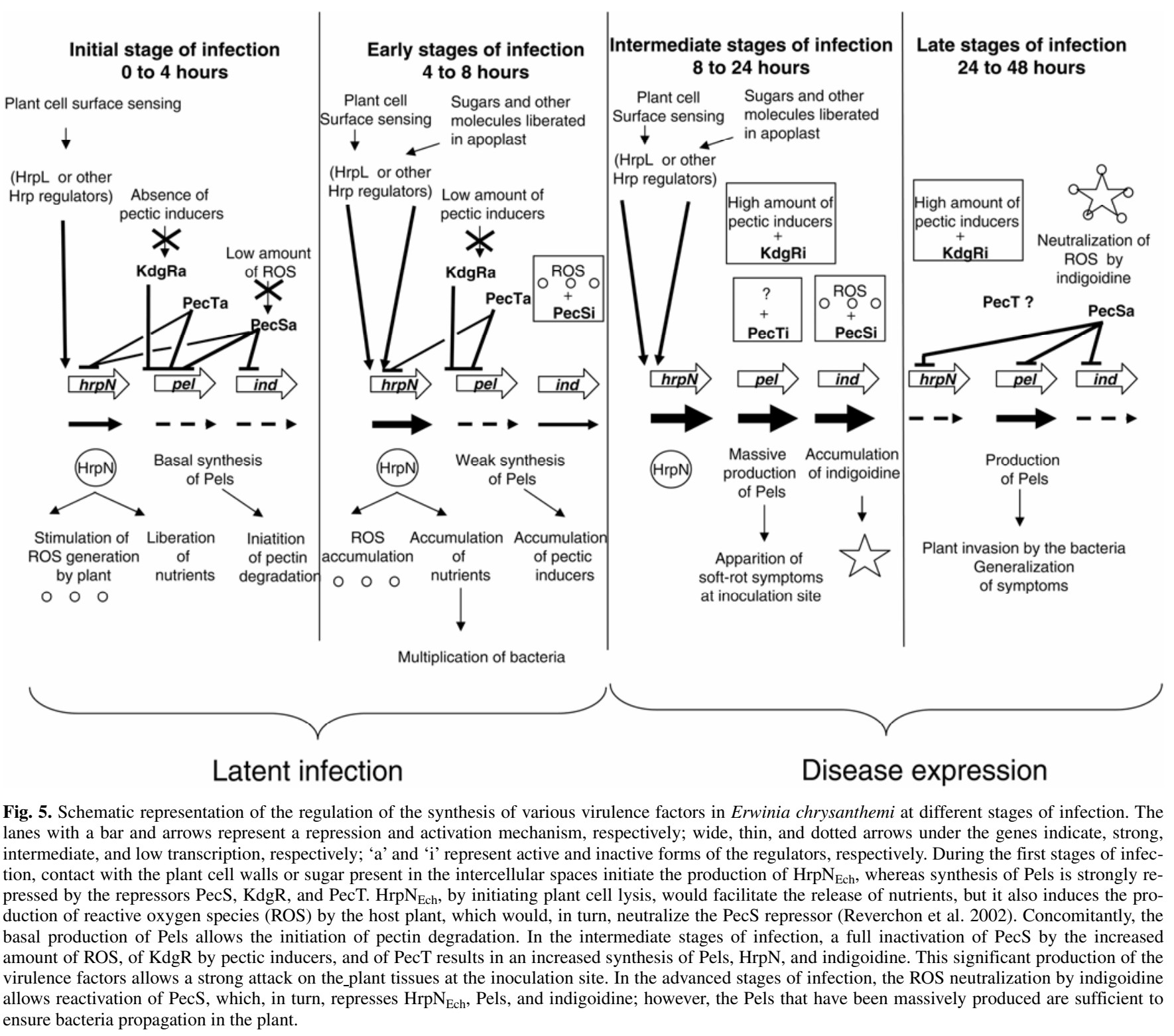

Vol. 18, No. 11, 2005 / 1211 
This feature reinforces the pleiotropic action of these two regulators on virulence factor production in E. chrysanthemi because previous observations have shown that PecS and PecT, in addition to the control of Pel production, also affect various other virulence-associated factors such as motility, production of cellulases, EPS synthesis, or production of indigoidine (Castillo and Reverchon 1997; Condemine et al. 1999; Reverchon et al. 1994, 2002; Surgey et al. 1996). A coregulation of the synthesis of $\mathrm{HrpN}_{E c h}$ and Pels by PecT and PecS was not documented in E. carotovora, where the link between these two virulence factors mainly is ensured by cellular density via the quorumsensing signal OHHL, produced by the synthase ExpI, and via the RNA-binding protein RsmA (Mukherjee et al. 1997). The possibility, in E. chrysanthemi, of a nonidentified quorumsensing system controlling Pel synthesis, as well as that of the Hrp system, cannot be disregarded. Furthermore, homologues of PecS and PecT have been found in E. carotovora, where they control the synthesis of Pels (Bell et al. 2002; Harris et al. 1998; Matsumoto et al. 2003). Equally, the involvement of these two regulators in the control of HrpN synthesis in $E$. $c a$ rotovora cannot be excluded. In vitro DNA-protein interaction experiments allowed the identification of the $h r p N_{E c h}$ DNA segment that specifically interacts with PecS. The PecS-protected region is between 80 to $114 \mathrm{bp}$ upstream of the transcription initiation site. Binding of PecS on this region would result in the inhibition of the transcript elongation from the $h r p N_{E c h}$ promoter.

By integrating these results with the data accumulated over recent years, we are able to propose a model to describe how the synthesis of Pels and $\mathrm{HrpN}_{E c h}$ might be regulated in $E$. chrysanthemi during infection. Upon entering the plant, the bacterium faces nutritional starvation with regard to iron (Neema et al. 1993) and other metabolites in the apoplast. $\mathrm{HrpN}_{E c h}$ and other factors secreted by the type III system might help in this initiation step. Indeed, HrpN from $P$. syringae has been shown to form ion-conducting pores in lipid bilayers which could facilitate the release of nutrients from the host plant as well as the introduction of bacterial virulence factors in the host cells (Lee et al. 2001). During the first steps of infection, contact with the plant cell walls or sugar present in the intercellular spaces could initiate the stimulation of $\mathrm{HrpN}_{E c h}$ production, whereas the pel genes mostly are repressed by the strong KdgR repressor, indicated by the relatively low amount of pectin-degradative products present in the plant intercellular spaces. $\mathrm{HrpN}_{E c h}$ also induces the plant defense reactions, in particular the production of ROS, which are believed to inactivate the PecS regulator (Reverchon et al. 2002). After a certain time, the basal production of Pels allows the initiation of pectin degradation (during the first $4 \mathrm{~h}$ after infection) (Figs. 3 and 5). During the early stages of infection (e.g., between 4 and $8 \mathrm{~h}$ after infection) (Figs. 3 and 5), inactivation of PecS by the increased amount of ROS has two consequences: stronger production of $\mathrm{HrpN}_{E c h}$ and of the radical scavenger pigment indigoidine. During the intermediate stage of infection (e.g., between 8 and $24 \mathrm{~h}$ after infection), a simultaneous inactivation of PecS by ROS, of KdgR by pectic inducers, and probably of PecT by an unknown signal, results in an increased production of $\mathrm{HrpN}_{E c h}$, Pels, and indigoidine. This strong production of the co-regulated virulence factors allows a strong attack on the host plant and the development of soft rot symptoms at the inoculation site. Finally, in the advanced stages of infection (e.g., $48 \mathrm{~h}$ after infection) (Figs. 3 and 5), the ROS neutralization by indigoidine results in a reactivation of PecS, which in turn represses $\mathrm{HrpN}_{E c h}$, Pels, and indigoidine synthesis. However, this effect on Pel synthesis is certainly less pronounced because the KdgR and probably the PecT repressors are no longer active. At this stage of infection, the plant defense reactions are neutralized and the plant cell-wall-degrading enzymes massively produced are sufficient to ensure the plant invasion by the bacteria.

The sequencing of the E. chrysanthemi 3937 genome (University of Wisconsin, Madison, WI, U.S.A.) recently has opened new avenues for more accurate studies of the regulatory network in this bacterium and for more precise investigations regarding the relationship between the different virulence factors. Identification of the PecS and PecT regulons using global approaches, such as transcriptome analysis or in vivo expression technology, will provide new insights into the mechanisms used by Erwinia spp. to evade host defenses and cause disease.

\section{MATERIALS AND METHODS}

\section{Bacterial strains, plasmids, culture conditions, and DNA manipulation techniques.}

Bacterial strains and plasmids used in this study are described in Table 1. E. chrysanthemi and Escherichia coli were grown at 30 and $37^{\circ} \mathrm{C}$, respectively. The rich medium used was LB medium; we used M63 or M9 minimal salts medium (Miller 1972) supplemented with a carbon source (polygalacturonate at $0.4 \%[\mathrm{wt} / \mathrm{vol}]$ or glycerol at $0.2 \%$ [wt/vol]). To test the effects of carbon sources on $h r p N_{E c h}$ expression, bacteria were grown in the minimal salts medium M63 supplemented with sucrose, glucose, fructose, arabinose, or glycerol at $0.4 \%$ (wt/vol). Media were solidified by the addition of $1.5 \%$ agar. When required, the antibiotics were as follows: ampicillin at $100 \mu \mathrm{g} / \mathrm{ml}$, kanamycin and chloramphenicol at $50 \mu \mathrm{g} / \mathrm{ml}$, or streptomycin at 20 $\mu \mathrm{g} / \mathrm{ml}$. DNA manipulations were performed using standard methods (Sambrook et al. 1989).

The plasmid pWN3013 was generated by cloning the $h r p N_{E c h}$ regulatory region $(424 \mathrm{bp},-323$ to +101 relative to the translation initiation codon ATG) in the vector pGEM-T (Stratagene, La Jolla, CA, U.S.A.). The hrpNEch regulatory region was generated using polymerase chain reaction with primer hrpND (5'-GATGTGTTGATCCTCTGGTG-3') and primer hrpNPext2 (5'-GGATGACGTAGCGGAGTTC-3') using genomic DNA from Erwinia chrysanthemi A350 as template. The primers hrpND and hrpNPext2 were complementary to -323 to -304 and +83 to +101 , respectively (relative to the $h r p N_{E c h}$ translation initiation codon ATG).

\section{Genetic techniques.}

Mutagenesis with MudI1734 on plasmid pCPN2 carrying the $h r p N$ gene was performed as described previously (Boccara et al. 1988). Localization of the site of insertion was determined precisely by sequencing with a $\mathrm{Mu}$ end primer $\left(5^{\prime}-\mathrm{C}\right.$ CGAATAATCCAATGTCC-3'). Transduction with phage phiEC2 was performed as described by Résibois and associates (1984).

\section{Protein and enzyme assays.}

$\beta$-Galactosidase and $\beta$-glucuronidase assays were performed on cell extracts treated with toluene. $\beta$-Galactosidase activity was measured by monitoring the degradation of $o$-nitrophenyl$\beta$-D-galactoside into $o$-nitrophenol that absorbs at $420 \mathrm{~nm}$, as described by Miller (1972). $\beta$-Glucuronidase activity was measured by monitoring the degradation of $p$-nitrophenyl- $\beta$-D-glucuronide into $p$-nitrophenol that absorbs at $405 \mathrm{~nm}$ (Bardonnet and Blanco 1992). Specific activity for both enzymes is expressed as nanomoles of product liberated per minute per milligram (dry weight) of bacteria. For growth in synthetic medium, bacterial concentration was estimated by measuring turbidity at $600 \mathrm{~nm}$ given that an OD of 1.0 at $600 \mathrm{~nm}$ corresponds to 
$10^{9} \mathrm{bacteria} / \mathrm{ml}$ and to $0.47 \mathrm{mg}$ of bacteria (dry weight) per milliliter. When grown on solid medium, the bacteria were first resuspended in $\mathrm{NaCl} 0.9 \%$ and an aliquot was used for assays.

To study the activities in planta, $2 \times 10^{6}$ bacteria contained in $5 \mu \mathrm{l}$ of M63 medium were deposited on a witloof chicory leaf, maintained during the experiment in a moist chamber at $28^{\circ} \mathrm{C}$. Pieces of tissue were collected at set times and resuspended in $0.9 \% \mathrm{NaCl}$, bacterial populations were counted by plating on LB agar medium supplemented with appropriate antibiotic, and an aliquot was used for enzyme assays as described previously (Masclaux and Expert 1995). Pectate lyase specific activity in rotted tissues was determined by the degradation of polygalacturonate to unsaturated products that absorb at $230 \mathrm{~nm}$ (Moran et al. 1968).

PecS was overproduced and purified as described previously (Praillet et al. 1996).

\section{Plant tests.}

Witloof chicory leaves from the Mouffetard market (Paris), maintained in a moist atmosphere at $28^{\circ} \mathrm{C}$, were inoculated, without wounding, with $2 \mu \mathrm{l}$ of bacterial suspension $\left(5 \times 10^{8}\right.$ $\mathrm{CFU} / \mathrm{ml})$. The surface of the maceration was recorded daily.

\section{RNA isolation and primer extension analysis.}

RNA extraction and normalization, as well as primer extension experiments, were performed essentially as previously described (Reverchon et al. 1997). The primer hrpNPext 2 used for the specific detection of mRNA was $5^{\prime}$ end labeled. The extension products were resolved on a $6 \%$ sequencing gel and visualized by autoradiography on Amersham MP film. The length of the transcripts was identified using the corresponding dideoxy sequencing reactions as a reference.

\section{In vitro DNA-protein interaction.}

Band-shift assay and DNase I footprinting were performed as described previously (Praillet et al. 1996). The regulatory region of the hrpN DNA fragment (PhrpN) was recovered from plasmid pWN3013 by a SalI-SacII digestion. The 465bp DNA fragment obtained was further end labeled by filling up the SalI extremity in the presence of $\left(\alpha-{ }^{32} \mathrm{P}\right) \mathrm{dCTP}(3000$ $\mathrm{Ci} / \mathrm{mmol}$, Amersham Biosciences, Piscataway, NJ, U.S.A.) and the Klenow fragment of DNA polymerase. The labeled DNA was purified after electrophoresis on agarose gel using the Qiagen gel extraction kit (Qiagen, Chatsworth, CA, U.S.A.). The signals obtained were detected by autoradiography on Amersham MP film and quantified using ImageMaster TotalLab software (version 2.01; Amersham Biosciences). The apparent $K_{\mathrm{d}}$ was determined as described earlier (Nasser et al. 1994).

\section{ACKNOWLEDGMENTS}

This work was supported by grants from the Institut de la Recherche Agronomique (INRA), from the Ministère Délégué à la Recherche et aux Nouvelles Technologies, from the Centre National de la Recherche Scientifique (CNRS), and from Programme de Microbiologie 2003 (ACIM-217). We thank G. Boccara-Jones and V. James for the English corrections; A. Buchet for critical reading of the manuscript; and our colleagues G. Condemine, V. Shevchik, and N. Hugouvieux-Cotte-Pattat for their support and advice.

\section{LITERATURE CITED}

Alfano, J. R., Bauer, D. W., Milos, T. M., and Collmer, A. 1996. Analysis of the role of the Pseudomonas syringae pv. syringae HrpZ harpin in elicitation of the hypersensitive response in tobacco using functionally non polar deletion mutations, truncated HrpZ fragments and hrmA mutations. Mol. Microbiol. 19:715-728.

Alfano, J. R., and Collmer, A. 1997. The type III (Hrp) secretion pathway of plant pathogenic bacteria: trafficking harpins, Avr proteins, and death. J. Bacteriol. 179:5655-5662.

Bardonnet, N., and Blanco, C. 1992. uidA antibiotic resistance cassettes for insertion mutagenesis, gene fusion and genetic constructions. FEMS (Fed. Eur. Microbiol. Soc.) Microbiol. Lett. 93:243-248.

Barras, F., Van Gijsegem, F., and Chatterjee, A. K. 1994. Extracellular enzymes and pathogenesis of soft-rot Erwinia. Annu. Rev. Phytopathol. 32:201-234.

Bauer, D. W., Wei, Z.-M., Beer, S. V., and Collmer, A. 1994. Erwinia chrysanthemi hrp genes and their involvement in soft rot pathogenesis and elicitation of the hypersensitive response. Mol. Plant-Microbe Interact. 7:573-581.

Bauer, D. W., Wei, Z.-M., Beer, S. V., and Collmer, A. 1995. Erwinia chrysanthemi harpin $\mathrm{Ech}_{\mathrm{Ec}}$ an elicitor of the hypersensitive response that contributes to soft-rot pathogenesis. Mol. Plant-Microbe Interact. 8:484491.

Bell, K. S., Avrova, A. O., Holeva, M. C., Cardle, L., Morris, W., De Jong, W., Toth, I. K., Waugh, R., Bryan, G. J., and Birch, P. R. J. 2002. Sample sequencing of a selected region of the genome of Erwinia carotovora subsp. atroseptica reveals candidate phytopathognicity genes and allows comparison with Escherichia coli. Microbiology 148:13671378 .

Berlyn, M. K. B. 1998. Linkage map of Escherichia coli K-12, edition 10: the tradition map. Microbiol. Mol. Biol. Rev. 62:814-984.

Bertheau, Y., Madgidi-Hervan, E., Kotoujansky, A., Nguyen-The, C., Andro, T., and Coleno, A. 1984. Detection of depolymerase isoenzymes after electrophoresis or electrofocusing, or in titration curves. Anal. Biochem. 139: 383-389.

Boccara, M., Diolez, A., Rouve, M., and Kotoujansky, A. 1988. The role of individual pectate lyases of Erwinia chrysanthemi 3937 in pathogenicity on Saintpaulia plants. Physiol. Mol. Plant Pathol. 33:95-104.

Boccara, M., Boué, C., Garmier, M., De Paepe, R., and Boccara, A. C. 2001. Infra-red thermography revealed a role for mitochondria in presymptomatic cooling during harpin-induced hypersensitive response. Plant J. 28:663-670.

Castilho, A. C., Olfson, P., and Casadaban M. J. 1984. Plasmid insertion mutagenesis and lac gene fusion with mini-Mu bacteriophage transposons. J. Bacteriol. 158:488-495.

Castillo, A., and Reverchon, S. 1997. Characterization of the pecT control region from Erwinia chrysanthemi strain 3937. J. Bacteriol. 179:49094918

Castillo, A., Nasser, W., Condemine, G., and Reverchon, S. 1998. The PecT repressor interacts with regulatory regions of pectate lyase genes in Erwinia chysanthemi. Biochim. Biophys. Acta. 1442:148-160.

Condemine, G., Dorel, C., Hugouvieux-Cotte-Pattat, N., and RobertBaudouy, J. 1992. Some of out genes involved in the secretion of pectate lyases in Erwinia chrysanthemi are regulated by $k d g R$. Mol. Microbiol. 6:3199-3211.

Condemine, G., Castillo, A., Passeri, F., and Enard, C. 1999. The PecT repressor coregulates synthesis of exopolysaccharides and virulence factors in Erwinia chrysanthemi. Mol. Plant-Microbe Interact. 12:45-52.

Dangl, J. L., and Jones, J. D. 2001. Plant pathogens and integrated defence responses to infection. Nature 411:826-833.

Desikan, R., Reynolds, A., Hancock, J. T., and Neill, S. J. 1998. Harpin and hydrogen peroxide both initiate programmed cell death but have differential effects on defence gene expression in Arabidopsis suspension cultures. Biochem. J. 330:115-120.

El Hassouni, M., Chambost, J. P., Expert, D., Van Gijsegem F., and Barras F. 1999. The minimal gene set member $m s r A$, encoding peptide methionine sulfoxide reductase, is a virulence determinant of the plant pathogen Erwinia chrysanthemi. Proc. Natl. Acad. Sci. U.S.A. 96:887892.

Expert, D. 1999. Withholding and exchanging iron: Interactions between Erwinia spp. and their hosts. Annu. Rev. Phytopathol. 37:307-334.

Favey, S., Labesse, G., Vouille, V., and Boccara, M. 1995. The flavohemoglobine HmpX: a new determinant of Erwinia chrysanthemi virulence. Microbiology 141:863-871.

Franza, T., Sauvage, C., and Expert, D. 1999. Iron regulation and pathogenicity in Erwinia chrysanthemi 3937: role of the Fur repressor protein. Mol. Plant-Microbe Interact. 12:119-128.

Frederick, R. D., Ahmad, M., Majerczak, D. R., Arroyo-Rodriguez, A. S., Manulis, S., and Coplin, D. L. 2001. Genetic organization of the Pantoea stewartii subsp. stewartii hrp gene cluster and sequence analysis of the $h r p A, h r p C, h r p N$, and wstE operons. Mol. Plant-Microbe Interact. 14:1213-1222.

Ham, J. H., Cui, Y., Alfano, J. R., Rodriguez-Palenzuela, P., Rojas, C. M., and Collmer, A. 2004. Analysis of Erwinia chrysanthemi EC16 pelE::uidA, pelL::uidA, and hrpN::uidA mutants reveals strain-specific atypical regulation of the Hrp type III secretion system. Mol. PlantMicrobe Interact. 17:184-194. 
Hauben, L., Moore, E. R. B., Vauterin, L., Steenackers, M., Mergaert, J., Verdonck, L., and Swings, J. 1998. Phylogenetic position of phytopathogens within the Enterobacteriaceae. Appl. Microbiol. 21:384397.

Harris, S. J., Shih, Y. L., Bentley, S. D., and Salmond, G. P. C. 1998. The hexA gene of Erwinia carotovora encodes a LysR homologue and regulates motility and the expression of multiple virulence determinants. Mol. Microbiol. 28:705-717.

Hugouvieux-Cotte-Pattat, N., and Robert-Baudouy, J. 1985. Lactose catabolism in Erwinia chrysanthemi. J. Bacteriol. 162:248-255.

Hugouvieux-Cotte-Pattat, N., and Robert-Baudouy, J. 1992. Analysis of the regulation of the pelBC genes in Erwinia chrysanthemi 3937. Mol. Microbiol. 6:2363-2376.

Hugouvieux-Cotte-Pattat, N., Dominguez, H., and Robert-Baudouy, J. 1992. Environmental conditions affect transcription of the pectinase genes of Erwinia chrysanthemi 3937. J. Bacteriol. 174:7807-7818.

Hugouvieux-Cotte Pattat, N., Condemine, G., Nasser, W., and Reverchon, S. 1996. Regulation of pectinolysis in Erwinia chrysanthemi. Annu. Rev. Microbiol. 50:213-258.

Hutcheson, S. W., 1997. The hrp-encoded protein export systems of Pseudomonas syringae and other plant pathogenic bacteria and their role in pathogenicity. Pages 145-179 in: Plant-Microbe Interactions, Vol.3. G. Stacey and N. T. Keen, eds. Chapman \& Hall, New York.

Kotoujansky, A., Lemattre, M., and Boistard, F. 1982. Utilization of thermosensitive episome bearing transposon $\mathrm{Tn} 10$ to isolate Hfr donor strain of Erwinia carotovora subsp. chrysanthemi. J. Bacteriol. 150:122-131.

Krause, M., and Durner, J. 2004. Harpin inactivates mitochondria in Arabidopsis suspension cells. Mol. Plant-Microbe Interact. 17:131-139.

Lee, J., Klusener, B., Tsiamis, G., Stevens, C., Neyt, C., Tampakaki, A. P., Panopoulos, N. J., Noller, J., Weiler, E. W., Cornelis, G. R., Mansfield, J. W., and Nurnberger, T. 2001. HrpZ(Psph) from the plant pathogen Pseudomonas syringae pv. phaseolicola binds to lipid bilayers and forms an ion-conducting pore in vitro. Proc. Natl. Acad. Sci. U.S.A. 98: 289-294.

Lopez-Solanilla, E., Garcia-Olmedo, F., and Rodriguez-Palenzuela, P. 1998. Inactivation of the sapA to sapF locus of Erwinia chrysanthemi reveals common features in plant and animal bacterial pathogenesis. Plant Cell. 10:917-924.

Masclaux, C., and Expert, D. 1995. Signaling potential of iron in plantmicrobe interactions: the pathogenic switch of iron transport in Erwinia chrysanthemi. Plant J. 7:121-128.

Masclaux, C., Hugouvieux-Cotte-Pattat, N., and Expert, D. 1996. Iron is a triggering factor for differential expression of Erwinia chrysanthemi strain 3937 pectate lyases in pathogenesis of African violets. Mol. Plant-Microbe Interact. 9:198-205.

Matsumoto, H., Jitareerat, P., Baba, Y., and Tsuyumu, S. 2003. Comparative study of regulatory mechanisms for pectinase production by $\mathrm{Er}$ winia carotovora subsp. carotovora and Erwinia chrysanthemi. Mol. Plant-Microbe Interact. $16: 226-237$.

Miller, J. H. 1972. Experiments in Molecular Genetics. Cold Spring Harbor Laboratory Press, Cold Spring Harbor, NY, U.S.A.

Moran, F., Nasuno, S., and Starr, M. P. 1968. Extracellular and intracellular polygalacturonic acid trans-eliminases of Erwinia carotovora. Arch. Biochem. Biophys. 123:293-306.

Mukherjee, A., Yaya, C., Yang, L., and Chatterjee, A. K. 1997. Molecular characterization and expression of the Erwinia carotovora $h r p N_{\mathrm{Ecc}}$ gene, which encodes an elicitor of the hypersensitive reaction. Mol. Plant-Microbe Interact. 10:462-471.

Nasser, W., and Reverchon, S. 2002. H-NS-dependent activation of pectate lyases synthesis in the phytopathogenic bacterium Erwinia chrysanthemi is mediated by the PecT repressor. Mol. Microbiol. 43:733-748

Nasser, W., Reverchon, S., and Robert-Baudouy, J. 1992. Purification and characterization of $\mathrm{KdgR}$ protein, a major repressor of pectinolysis genes of Erwinia chrysanthemi. Mol. Microbiol. 6:257-265.

Nasser, W., Reverchon, S., Condemine, G., and Robert-Baudouy, J. 1994. Specific interactions of Erwinia chrysanthemi KdgR repressor with different operators of genes involved in pectinolysis. J. Mol. Biol. 236:427-440

Nasser, W., Robert-Baudouy, J., and Reverchon, S. 1997. Antagonistic effect of CRP and KdgR in the transcription control of the Erwinia chrysanthemi pectinolysis genes. Mol. Microbiol. 26:1071-1082.

Nasser, W., Bouillant, M. L., Salmond, G. P. C., and Reverchon, S. 1998. Characterization of the Erwinia chrysanthemi expI-expR locus directing the synthesis of two $N$-acyl-homoserine lactone signal molecules. Mol. Microbiol. 29:1391-1405.

Neema, C., Laulhère, J.-P., and Expert, D. 1993. Iron deficiency induced by chrysobactin in Saintpaulia ionantha leaves inoculated with Erwinia chrysanthemi. Plant Physiol. 102:967-973.

Nomura, K., Nasser, W., Kawagishi, H., and Tsuyumu, S. 1998. The pir gene of Erwinia chrysanthemi EC16 regulates hyperinduction of pec- tate lyase virulence genes in response to plant signals. Proc. Natl. Acad. Sci. U.S.A. 95:14034-14039.

Pérombelon, M. C. M. 2002. Potato diseases caused by soft rot erwinias: an overview of pathogenesis. Plant Pathol. 51:1-12.

Praillet, T., Nasser, W., and Robert-Baudouy, J. 1996. Purification and functional characterization of PecS: a regulator of virulence factor synthesis in Erwinia chrysanthemi. Mol. Microbiol. 20:391-402.

Reeves, P. J., Whitcombe, D., Wharam, S., Gibson, M., Allison, G., Bunce, N., Barallon, R., Douglas, P., Mulholland, V., Stevens, S., Walker, D., and Salmond G. P. C. 1993. Molecular cloning and characterization of 13 out genes from Erwinia carotovora subspecies carotovora: genes encoding members of a general secretion pathway (GSP) widespread in gram-negative bacteria. Mol. Microbiol. 8: 443456.

Résibois, A., Colet, M., Faelen, M., Schoonejans, E., and Toussaint, A. 1984. PhiEC2, a new generalized transducing phage of Erwinia chrysanthemi. Virology 137:102-112.

Reverchon, S., and Robert-Baudouy, J. 1987. Regulation of the expression of pectate lyase genes pelA, pelD, and pelE in Erwinia chrysanthemi. J. Bacteriol. 169:2417-2423.

Reverchon, S., Nasser, W., and Robert-Baudouy, J. 1991. Characterization of $k d g R$, a gene of Erwinia chrysanthemi that regulates pectin degradation. Mol. Microbiol. 5:2203-2216.

Reverchon, S., Nasser, W., and Robert-Baudouy, J. 1994. pecS: a locus controlling pectinase, cellulase and blue pigment production in Erwinia chrysanthemi. Mol. Microbiol. 11:1127-1139.

Reverchon, S., Nasser, W., and Robert-Baudouy, J. 1997. The cyclic AMP receptor protein is the main activator of the pectinolysis genes in Erwinia chrysanthemi. J. Bacteriol. 179:3500-3508.

Reverchon, S., Rouanet, C., Expert, D., and Nasser, W. 2002. Characterization of indigoidine biosynthetic genes in Erwinia chrysanthemi and role of this blue pigment in pathogenicity. J. Bacteriol. 184:654-665.

Rouanet, C., Reverchon, S., Rodionov, D. A., and Nasser, W. 2004. Definition of a consensus DNA-binding site for PecS, a global regulator of virulence gene expression in Erwinia chrysanthemi and identification of new members of the PecS regulon. J. Biol. Chem 279:30158-30167

Sambrook, J., Fritsch, E. F., and Maniatis, T. 1989. Molecular Cloning: A Laboratory Manuel, 2nd ed. Cold Spring Harbor Laboratory Press, Cold Spring Harbor, NY, U.S.A

Santos, R., Franza, T., Laporte, M. L., Sauvage, C., Touati, D., and Expert, D. 2001. Essential role of superoxide dismutase on the pathogenicity of Erwinia chrysanthemi strain 3937. Mol. Plant-Microbe Interact. 14:758-767.

Scheel, D. 1998. Resistance response physiology and signal transduction. Curr. Opin. Plant Biol. 1:305-310.

Schoonejans, E., Expert, D., and Toussaint, A. 1987. Characterisation and virulence properties of Erwinia lipopolysaccharide-defective, phiEC2resistant mutants. J. Bacteriol. 169:4011-4017.

Surgey, N., Robert-Baudouy, J., and Condemine, G. 1996. The Erwinia chrysanthemi PecT gene regulates pectinase gene expression. J. Bacteriol. 178:1593-1599.

Wei, Z. M., and Beer, S. V. 1995. hrpL activates Erwinia amylovora hrp gene transcription and is a member of the ECF subfamily of $\sigma$ factors. J. Bacteriol. 177:6201-6210.

Wei, Z. M., Laby, R. J., Zumoff, C. H., Bauer, D. W., He, S. Y., Collmer, A., and Beer, S. V. 1992. Harpin, elicitor of the hypersensitive response produced by the plant pathogen Erwinia amylovora. Science 257:85-88.

Xiao, F, Goodwin, S. M., Xiao, Y., Sun, Z., Baker, D., Tang, X., Jenks, M. A., and Zhou, J. M. 2004. Arabidopsis CYP86A2 represses Pseudomonas syringae type III genes and is required for cuticle development. EMBO (Eur. Mol. Biol. Organ.) J. 23:2903-2913.

Xie, Z. X., and Chen, Z. X. 2000. harpin-induced hypersensitive cell death is associated with altered mitochondrial functions in tobacco cells. Mol. Plant-Microbe Interact. 13:183-190.

Yang, C. H., Gavilanes-Ruiz, M., Okinaka, Y., Vedel, R., Berthuy, I., Boccara, M., Chen, J. W., Perna, N. T., and Keen, N. T. 2002. hrp genes of Erwinia chrysanthemi 3937 are important virulence factors. Mol. Plant-Microbe Interact. 15:472-80.

Yap, M. N., Yang, C. H., Barak, J. D., Jahn, C. E., and Charkowski, A. O. 2005. The Erwinia chrysanthemi type III secretion system is required for multicellular behavior. J. Bacteriol. 187:639-648.

\section{AUTHOR-RECOMMENDED INTERNET RESOURCE}

University of Wisconsin-Madison, Department of Animal Health and Biomedical Sciences, Genome Evolution Laboratory Erwinia chrysanthemi 3937 genome webpage: asap.ahabs.wisc.edu 